\title{
Wojciech Zyzak
}

Uniwersytet Papieski Jana Pawła II w Krakowie

\section{Mistrzowie życia duchowego o rozeznawaniu duchów}

\section{Próba definicji rozeznawania duchów}

Ponieważ każda próba definicji pojęcia musi zakładać analizę etymologii, należy wziąć pod uwagę fakt, że rozeznanie w języku teologii chrześcijańskiej sięga do greckiego słowa dokimadzein, co oznacza „poddawać próbie”, „badać”, oraz diacrinein, czyli „osądzać właściwie”, „rozpoznawać”, „analizować”. Łacińska forma discernere oznacza obserwację przedmiotu lub rzeczywistości. W najbardziej klasycznej, wąskiej postaci rozeznawanie duchów oznacza praktykę duchową wywodzącą się z Biblii i rozwiniętą przez Ojców pustyni oraz Ojców Kościoła, polegającą na uległości Duchowi Świętemu, zwłaszcza Jego natchnieniom, a także na przyjmowaniu darów i charyzmatów umożliwiających poznanie przekraczające uzdolnienia naturalne ${ }^{1}$. W szerszym sensie roze-

${ }^{1}$ J.K. Miczyński, Rozeznawanie duchowe, [w:] Encyklopedia Katolicka, t. 17, E. Gigilewicz (red.), Lublin 2012, k. 426. 
znanie duchów, lub rozeznanie duchowe, jest istotnym przejawem życia duchowego człowieka i wymaga umiejętności pozwalających osądzić pojawiające się w nim poruszenia².

Z rzeczywistością rozeznania duchów mamy do czynienia w całej historii zbawienia, począwszy od okresu biblijnego. W Starym Testamencie rozeznawanie duchów nie jest znane jako termin, lecz jako praktyka. Najpierw chodzi o różnorakie wybory, w których człowiek musi podjąć decyzję (por. Rdz 2,17; 4,7; 12,4; Wj 19,8). Wymagają one prawdziwego rozeznania, skoro odzywa się w człowieku też inny głos, głos szatana, który wydaje się pochodzić z serca człowieka (por. Rdz 6,5) lub z zewnątrz (por. Rdz 3). Początkowo trudno mówić o rozeznawaniu duchów, gdyż wydają się tak mocne, że nie można im się oprzeć, oraz dlatego, że ich źródłem, zarówno dobrych, jak i złych, jest Jahwe (por. $1 \mathrm{Krl} 22,19-23$ ). Powoli zaczęto odróżniać niepomyślne złe duchy pochodzące od Jahwe (por. 1 Sm 19,9) od duchów Jahwe, których skutki są zawsze dobre: „Saula natomiast opuścił duch Pański, a opętał go duch zły, zesłany przez Pana" (1 Sm 16,14). W epoce proroków zrodziła się konieczność odróżnienia prawdziwych proroków od fałszywych, którzy zwodzą lud ${ }^{3}$. W Nowym Testamencie znajdujemy rozeznanie przeżywane w Ewangeliach i reflektowane w listach. Jezus, demaskując szatana, objawił swą władzę nad złymi duchami. Mocą Ducha wypędzał czarty (por. Mt 8,16). Taką samą władzę dał też swym uczniom. Święty Paweł w 1 Kor 12, 10 wymienia pośród darów Ducha rozezna-

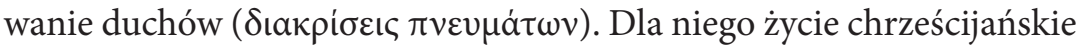
jest stałym rozeznawaniem, by strzec się dróg grzechu i szukać zawsze tego, co lepsze (por. Rz 12,2). Rozeznawanie duchów jest w jego ujęciu owocem charyzmatu i wraz $\mathrm{z}$ darem proroctwa ma za przedmiot ukazywanie tajemnic serca ${ }^{4}$.

${ }^{2}$ A. Barruffo, Discernimento, [w:] Nuovo dizionario di spiritualità, Torino 1985, s. $419-430$.

${ }^{3}$ J. Guillet, Discernement des esprits. I. Dans l'Écriture, [w:] Dictionnaire de Spiritualité, t. 3, Paris 1957, k. 1222-1224.

${ }^{4}$ J. Guillet, Discernement des esprits. I. Dans l'Écriture, k. 1231-1244; Duch, [w:] Słownik Teologii Biblijnej, X. Leon-Dufour (red.), Poznań-Warszawa 1973, s. 225. 
Pośród Ojców Kościoła Jan Kasjan zajmował się rozeznaniem duchów głównie w dziełach: Reguły życia mnichów i leczenie ośmiu grzechów głównych oraz Rozmowy z Ojcami. W jego rozumieniu rozeznanie duchów jest nauką, która kieruje procesami decydowania na podstawie prawdziwego poznania i osądu (verum iudicium et scientia) ${ }^{5}$. W chrześcijańskiej tradycji łacińskiej sancta discretio stanowi szczególną pieczęć świętości benedyktyńskiej. Potrzeba jej szczególnie, gdy trzeba kierować duszami, co święty Benedykt zapisał w rozdziale 64 swej Reguty. To rozeznanie jest matką cnót i darem Ducha Świętego, który poznaje myśli serca, choć w istocie to rozeznanie należy do każdego z siedmiu darów ${ }^{6}$. Również zdaniem świętego Bernarda z Clairvaux discretio spirituum jest rozumiana jako charyzmat Ducha. Dzięki Niemu człowiek może odróżnić dary na własny użytek od darów dla dobra społecznego, a przede wszystkim inspiracje złych duchów od natchnień Ducha Świętego. Zdaniem Bernarda darowi discretio odpowiada cnota discretio, która nie ma tego samego aspektu charyzmatycznego i winna cechować głównie przełożonych ${ }^{7}$. Podobnie ujmują kwestię późniejsi autorzy, pośród których najważniejsi, to: Jan Ruusbroec, Tomasz a Kempis, św. Bernardyn ze Sieny, Jan Gerson i Dionizy Kartuz. Ostatni z nich uważa discretio za formę roztropności ${ }^{8}$. Najbardziej wpływowy średniowieczny teolog, Tomasz z Akwinu nie wymienił rozeznania w traktacie o roztropności. Dla niego jest to charyzmat, rodzaj „instynktu nadprzyrodzonego”, dzięki któremu poznaje się intuicyjnie boskie lub inne pochodzenie myśli i pragnień. Rozeznanie duchowe należy do aktów roztropności wlanej9.

${ }^{5}$ A. Nocoń, Władza złych duchów nad człowiekiem według Jana Kasjana, „Vox Patrum" 33(2013)59, s. 198n.

${ }^{6}$ E. Stein, Sancta discretio, [w:] Edith Stein Gesamtausgabe. Geistliche Texte II, Freiburg im Breisgau 2007, s. 114-117.

${ }^{7}$ F. Vandenbroucke, Discernement des esprits. III. Au Moyen Age, w: Dictionnaire de Spiritualité, t. 3, Paris 1957, k. 1255-1257.

${ }^{8}$ F. Vandenbroucke, Discernement des esprits. III. Au Moyen Age, k. 1261-1266.

${ }^{9} \mathrm{H}$. Martin, Discernement des esprits. V. Discernement des esprits et direction spirituelle, [w:] Dictionnaire de Spiritualité, t. 3, Paris 1957, k. 1285; J. Pegon, Discernement des esprits. VI. Conclusion, [w:] Dictionnaire de Spiritualité, t. 3, Paris 1957, k. 1288n. 
Nowożytność pozostawała pod wpływem rozeznania duchowego zawartego w Ćwiczeniach świętego Ignacego z Loyoli. Mamy u niego do czynienia z teologiczną epistemologią, krytycznie ewaluującą poznanie Bożej woli. Znaczenie Ignacego podkreśla choćby twierdzenie wielkiego teologa Karla Rahnera, że specyficzne doświadczenie Boga, do którego prowadzi Ignacy w Ćwiczeniach, miało fundamentalne znaczenie dla jego własnej teologii ${ }^{10}$.

Niektórzy autorzy rozróżniają znaczeniowo rozeznawanie duchowe i rozeznawanie duchów, traktowane pod kątem przedmiotu poznania niezależnie od jego sposobu. Chodzi tu o czysto ludzkie rozeznawanie stanów człowieka powodowanych różnymi czynnikami. W takim rozumieniu rozeznawanie duchowe, a nie zwykłe rozeznanie duchów, dokonuje się na płaszczyźnie duchowej za pomocą zdolności nadprzyrodzonych i darów Ducha Świętego. Nie wyklucza to jednak mówienia o rozeznaniu duchów na gruncie działania Bożej łaski, czyli nie w sposób naturalistyczny ${ }^{11}$.

\section{Cel rozeznania duchów}

W Nowym Testamencie rozeznawanie znajdujemy przeżywane w Ewangeliach i reflektowane w listach. W Ewangeliach polega ono na rozpoznaniu w osobie i działaniu Jezusa mocy Ducha Bożego i porażki złego ducha. Celem rozeznania jest też rozpoznanie woli Bożej oraz sposobów działania złego ducha, czego przykład dał Jezus podczas kuszenia na pustyni (por. Mt 4,1-11). W Dziejach Apostolskich chodzi głównie o rozeznanie działania Ducha Świętego w Kościele ${ }^{12}$.

Te zawarte w Objawieniu cele rozeznania duchów znajdują w historii Kościoła swą kontynuację. Najogólniej można powiedzieć, że

${ }^{10}$ K. Waaijman, Handbuch der Spiritualität, t. 2, Mainz 2005, s. 188-190.

${ }^{11}$ J.K. Miczyński, Rozeznawanie duchowe, [w:] Encyklopedia Katolicka, t. 17, E. Gigilewicz (red.), Lublin 2012, k. 426n; M. Chmielewski, S. Urbański, Rozeznawanie duchowe, [w:] Leksykon duchowości katolickiej, Lublin-Kraków 2002, s. 757.

12 J. Guillet, Discernement des esprits, k. 1231-1238. 
w discretio chodzi o dojście do pełnego poznania siebie, by jak najlepiej przygotować się na poznanie Boga i Jego kontemplację. Cnota discretio jest ważna w cura animarum, gdyż pozwala spowiednikom i kierownikom duchowym prowadzić chrześcijan do doskonałości. Jako charyzmat ma na celu między innymi umożliwienie udowodnienia świadectwa o Bogu dzięki ujawnianiu sekretów serca. Charyzmat pozwala też odkryć, przez jakiego ducha człowiek jest pobudzany do działania, i osądzić fałszywych proroków ${ }^{13}$.

Całą gamę celów rozeznawania duchów znajdujemy w Ćwiczeniach Ignacego z Loyoli. Osobiste doświadczenie jezuity sprawiło, że podkreślił on wagę więzi rozeznania i wyboru, badając poruszenia w duszy celem odkrycia woli Bożej. Temu służą w Ćwiczeniach uwagi o wyborze na koniec drugiego tygodnia (169-189), reguły odróżniania różnych poruszeń w duszy (314-327), żeby lepiej odróżnić duchy (329-336), odkryć skrupuły i insynuacje złego ducha (345-351), celem ustalenia zadań do spełnienia w Kościele $(352-370)^{14}$. Cel zawarty jest już w pierwszym punkcie Ćwiczeń: „Ćwiczeniami Duchownymi nazywa się wszelkie sposoby przygotowania i usposobienia duszy do usunięcia wszystkich uczuć nieuporządkowanych, a po ich usunięciu - do szukania i znalezienia woli Bożej” (nr 1). Józef Augustyn, komentując ten punkt, podkreśla weryfikację uczuć jako cel rozeznania: „Nawrócenie domaga się od nas wejścia w świat naszych nieuporządkowanych uczuć. Poznać świat uczuć człowieka, to w pewnym sensie poznać samego człowieka, poprzez nasze uczucia ujawnia się bowiem to, co jest w nas najgłębsze: nasze pragnienia, tęsknoty, nadzieje, oczekiwania, ale także nasze potrzeby, obawy, lęki, niezadowolenia itd." ${ }^{15}$.

Dla duchowości chrześcijańskiej wielkie znaczenie ma także tradycja karmelitańska. Również w niej znajdujemy uwagi dotyczące celów

${ }^{13}$ F. Vandenbroucke, Discernement des esprits, k. $1257 \mathrm{n}$.

${ }^{14}$ J. Pegon, Discernement des esprits, k. 1266-1275.

${ }^{15}$ J. Augustyn, Świat ludzkich uczuć, [w:] Droga ćwiczeń, Czechowice-Dziedzice 1991, s. 20; J. Prusak, Strapienie i pocieszenie. Jak kierować się uczuciami w życiu duchowym, [w:] J. Augustyn, J. Kołacz (red.), Sztuka kierownictwa duchowego, Kraków 2013, s. $415-422$. 
rozeznania duchów. Święty Jan od Krzyża pisze w Drodze na górę Karmel $(2,30)$ i w Żywym płomieniu miłości $(3,3)$ o konieczności rozeznania duchów, czyli tendencji i wewnętrznych impulsów duszy, czy stanowią bodziec do prawdziwie, czy jedynie pozornie cnotliwego działania. W Drodze na górę Karmel $(2,22)$ święty pisze także o celu rozeznania wyjątkowych darów duchowych, gdyż te nadzwyczajne dary nie zawsze są autentycznymi charyzmatami Bożymi. Badanie ma tu na celu tropienie fałszywych mistyków. W tej samej tradycji święta Teresa Wielka, na podstawie własnych doświadczeń z kierownikami, którzy ocenili jej modlitwę jako pochodzącą od złego ducha (Księga Życia, 23), podkreśliła cel rozeznania duchów w postaci odróżnienia łask modlitwy mistycznej od jej zafałszowań ${ }^{16}$.

$\mathrm{Z}$ analizy nauczania klasyków duchowości wynika, że rozeznanie ma na celu: 1. Ocenę owoców, czyli skutków wydarzeń i czynów; 2. Ocenę wewnętrznych poruszeń pochodzących z działania ludzkiej natury, ducha dobrego lub złego; 3. Szukanie woli Bożej w powołaniu, misji i zadaniach w Kościele; 4. Ocenę moralnych postaw; 5. Regulowanie posługi apostolskiej i pastoralnej; 6. Ocenę rzeczywistości życia ludzkiego, między innymi politycznego i ekonomicznego ${ }^{17}$. Głównie jednak rozeznanie duchów dotyczy trzech dziedzin: 1. Wizji, słów, objawień; 2. Oświeceń i poruszeń wewnętrznych, inspiracji, które pojawiają się w sposób zwyczajny; 3 . Stanów pocieszeń i strapień ${ }^{18}$.

Współcześnie podkreśla się konieczność rozeznawania w kontekście całego duszpasterstwa, a zwłaszcza przepowiadania. Warto w tym kontekście zacytować fragment adhortacji papieża Franciszka Evangelii gaudium: „Czasem słuchając całkowicie ortodoksyjnego języka, ma się wrażenie, że to, co otrzymują wierni z racji języka, jakim się posługują i jaki rozumieją, jest czymś, co nie odpowiada prawdziwej Ewangelii Jezusa Chrystusa. Ze świętym zamiarem przekazania im prawdy o Bogu i człowieku, niekiedy przekazujemy im fałszywego boga lub ideał ludz-

\footnotetext{
${ }^{16}$ H. Martin, Discernement des esprits, k. 1281-1285.

${ }^{17}$ J.K. Miczyński, Rozeznawanie duchowe, k. 426.

${ }^{18}$ J. Pegon, Discernement des esprits, k. 1286.
} 
ki naprawdę niebędący chrześcijańskim. W ten sposób pozostajemy wierni jakiemuś sformułowaniu, ale nie przekazujemy istoty rzeczy. To jest najpoważniejsze ryzyko"19. W jednym z wywiadów papież doprecyzował: „Ktoś mógłby powiedzieć, że to relatywizm. Czy rzeczywiście? Tak, jeśli jest to źle rozumiane jako rodzaj niewyraźnego panteizmu. Nie, jeśli jest to rozumiane w sensie biblijnym, gdzie Bóg jest zawsze niespodzianką, a więc nigdy nie wiadomo, gdzie i jak Go spotykamy; to nie od nas zależy czas i miejsce spotkania z Nim. Trzeba więc rozeznać spotkanie. Dlatego rozeznanie jest rzeczą podstawową" ${ }^{20}$.

$\mathrm{Na}$ koniec warto dodać, że podejmowane są owocne próby budowania całej teologii w oparciu o pneumatologię i rozeznawanie duchów. Klasyczna teologia nie zna osobnego traktatu De Spiritu Sancto. Postulat pneumatologicznego odnowienia całej teologii prowadzi do ujęcia nie tylko doświadczeń w Duchu, ale także doświadczenia Ducha, Ducha Świętego Ojca i Syna. On uobecnia i wypełnia historię miłości Boga i ludzi, znajdującą kulminację w Jezusie Chrystusie. Dlatego trzeci artykuł Credo jest wyznaniem wiary w Ducha Świętego i Jego eschatologiczne, uświęcające działanie. To wymaga podwójnego ruchu w przeciwnych kierunkach: Kim jest Duch Święty winno wynikać z Jego działania, a z drugiej strony refleksja nad Jego istotą służy rozeznawaniu duchów ${ }^{21}$. O rozeznaniu duchów mówi się też w kontekście oceny religii niechrześcijańskich ${ }^{22}$.

${ }^{19}$ Franciszek, Adhortacja apostolska Evangelii gaudium, nr 41.

${ }^{20}$ A. Spadaro, Serce wielkie i otwarte na Boga. Wywiad z papieżem Franciszkiem, Dodatek do tygodnika „Gość Niedzielny” 2013, nr 40, s. 12; S. Semplici, Czas jest ważniejszy niż przestrzeń, „Społeczeństwo” 4(2014), s. 86.

${ }^{21}$ B.J. Hilberath, Pneumatologie, [w:] Handbuch der Dogmatik, t. 1, T. Schneider (red.), Düsseldorf 2006, s. 449n.

${ }^{22}$ R.A. Siebenrock, Die Wahrheit der Religionen und die Fülle der Selbstmitteilung Gottes in Jesus Christus, [w:] Herders Theologischer Kommentar zum Zweiten Vatikanischen Konzil, t. 5, Freiburg im Breisgau 2006, s. 130. 


\section{Kryteria rozeznania}

Z pewnymi kryteriami rozeznawania duchów mamy do czynienia już w Starym Testamencie w odniesieniu do posługi prorockiej. Prorok nieszczęść jest autentyczny, gdyż prorokuje zgodnie z tradycją prorocką, zaś prorok szczęścia jest prawdziwy, gdy wydarzenia weryfikują jego mowę (por. Jr 28,8n). Prawdziwy prorok na poparcie swego słowa proponuje znaki, które się spełniają, oraz dowody na to, że mówi w imieniu Boga (por. $1 \mathrm{Sm}$ 2,34). Nawet powodowanie czegoś nadzwyczajnego na potwierdzenie słowa proroka nie może wystarczyć za gwarancję, jeśli jego nauczanie jest sprzeczne $\mathrm{z}$ fundamentami religii Izraela (por. Pwt 13,2). Obok nauki również postępowanie proroka stanowi znak, przynajmniej negatywny. Grzeszne życie zdradza proroka fałszywego (por. Jr 23,14). Również intencja jest ważna. Jeśli prorokuje, by uczynić się popularnym, paktuje z grzechami ludu, jego przesłanie jest błędne (por. Jr 23,16n). Definitywnym kryterium, które przywołują prorocy, jest ich doświadczenie, dlatego opisują swe powołanie (por. Jr 1), pokazujące, że kontakt z Bogiem zmusza ich do przeciwstawienia słowa Bożego powszechnej opinii. Prorokując nieszczęście spowodowane grzechem ludu, prorok odwołuje się do tradycji religijnej. Ostatecznie kryterium rozeznania prorockiego jest zarazem subiektywne i obiektywne ${ }^{23}$.

W Nowym Testamencie można wyróżnić następujące kryteria rozeznawania duchów: owoce ciała i ducha (por. Ga 5,19-24), pełnienie woli Bożej (por. Mt 12,50; $1 \mathrm{~J}$ 2,4), pokora, prostota i roztropność (por. Mt 18,3), posłuszeństwo Nauczycielskiemu Urzędowi Kościoła (por. Mt 18,17), uczynki miłosierdzia (por. Mt 25,31-46), siła charakteru (por. Flp 4,13), prawda (zgodność z wiarą i moralnością w kontekście woli Bożej), miłość (por. $1 \mathrm{~J}$ 4,8), przyjęcie Chrystusa jako Pana

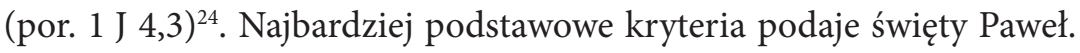
W jego ujęciu dobrego i złego ducha poznaje się po owocach, gdyż autentyczne dary budują Kościół. Duch dobry objawia się przez znaki

${ }^{23}$ J. Guillet, Discernement des esprits, k. 1225-1228.

${ }^{24}$ J.K. Miczyński, Rozeznawanie duchowe, k. 426n. 
mocy, cuda i pewność niesienia słowa Bożego podczas prześladowań. Pośród znaków bezpośrednia komunikacja z Bogiem w objawieniu jest fundamentalnym przeżyciem Pawła spod Damaszku. Jednak dla niego autentyczne objawienie sytuuje się $\mathrm{w}$ tradycji Objawienia powierzonego Kościołowi (por. 1 Kor 15,3-8). Prawdziwe dary cechują się światłem i pokojem. Pośród darów Ducha miłość braterska zajmuje najwięcej miejsca. Jest stałym znakiem Ducha i zasadą rozeznania. Dla Pawła najważniejszym kryterium rozeznania jest, podobnie jak w Ewangeliach, postawa wobec Jezusa Chrystusa (por. 1 Kor 12,3). Podobnie święty Jan stwierdza: „każdy duch, który uznaje, że Jezus Chrystus przyszedł $\mathrm{w}$ ciele, jest $\mathrm{z}$ Boga. Każdy zaś duch, który nie uznaje Jezusa, nie jest z Boga" (1 J 4,2n) ${ }^{25}$.

Ojcowie Wschodu, od „Pasterza” Hermasa po Orygenesa, w analizach bardziej psychologicznych, podają kryteria rozeznania dobrych i złych duchów po dziełach, do których inspirują. Na Zachodzie święty Augustyn w De civitate Dei $(14,28)$ podaje kryteria odróżniania państwa Boga i państwa demonów. Dwie miłości zbudowały dwa państwa: miłość siebie, aż do gardzenia Bogiem to państwo ziemskie, zaś miłość Boga aż do pogardy sobą to państwo Boże. Jedno szuka chwały w sobie, drugie w Panu. Jedno wymaga chwały od ludzi, drugie ma ją w Bogu. Jedno jest opanowane pasją rządzenia, w drugim obywatele sobie służą w miłości. Jedno pokłada siłę w sobie, drugie w Bogu. Jedno szuka mądrości ludzkiej, drugie kultu Boga. Później papież Grzegorz Wielki dzięki doświadczeniu duszpasterskiemu i życiu duchowemu przekazywał bardzo praktyczne nauczanie. Zwłaszcza w „Moralia” (IX, 13, 20) pisał, że czasami człowiek uważa za łaskę dar czynienia cudów, a on go prowadzi do pychy. Innym razem uważa pokusę za wyraz gniewu Bożego, a ona czyni go bardziej uważnym na cnotę. Tu szczególnie ważna jest prawda psychologiczna ${ }^{26}$. W Średniowieczu tacy autorzy, jak Bernard z Clairvaux, Jan Gerson, Dionizy Kartuz, Tomasz z Akwinu, Bo-

\footnotetext{
${ }^{25}$ J. Guillet, Discernement des esprits, k. 1238-1247.

${ }^{26}$ G. Bardy, Discernement des esprits. II. Chez les Pères, [w:] Dictionnaire de Spiritualité, t. 3, Paris 1957, k. 1247-1252.
} 
nawentura, Henryk Suzo czy Hugo od świętego Wiktora akcentowali pokorę i posłuszeństwo jako kryteria „dobrego ducha” ${ }^{27}$.

W okresie nowożytnym reguły zawarte w Ćwiczeniach świętego Ignacego łączą wszystkie elementy wcześniejszych tradycji: dobre i złe duchy, naturalne i preternaturalne wpływy, myśli i wyobraźnię, stany afektywności, pocieszenia i strapienia ${ }^{28}$. Ignacy akcentował istnienie trzech rodzajów myśli człowieka: własnych, ducha dobrego i ducha złego. Na tej podstawie później Reginald Garrigou-Lagrange zaprezentował ich charakterystykę oraz wynikające z nich postawy, sposoby działania duchów i możliwości ich rozpoznawania. Oznakami ducha przyrodzonego są: niechęć do umartwienia i upokorzenia, szukanie siebie, łakomstwo duchowe, porzucanie drogi życia wewnętrznego i praktyki cnót teologalnych oraz szukanie przyjemności w działaniu nadprzyrodzonym. Do oznak ducha diabelskiego należą głównie: pogłębianie pychy, zamęt, rozpacz, nieposłuszeństwo, pogoń za nadzwyczajnościami i nienawiść. Ducha Bożego charakteryzuje: roztropne umartwienie zewnętrzne, posłuszeństwo, pokora, ożywienie cnót teologalnych, radość, pokój, łagodność i opanowanie (por. Ga 5,22n) ${ }^{29}$. Jeden z najbardziej kompletnych wykazów cech ducha dobrego i złego podaje Giovanni Battista Scaramelli w dziele Discernimento degli spiriti z 1753 roku. W intelekcie dobrego ducha poznaje się po prawdzie, użyteczności, wewnętrznym świetle, pokorze itp. Złego ducha rozpoznaje się po błędzie, fałszywych światłach wyobraźni i pysze. W woli dobry duch zostaje poznany po pokoju, ufności w Bogu, prawej intencji, prostocie, wolności duchowej, miłości zapominającej o sobie. Zły duch wyraża się w zarozumiałości. Scaramelli ocenia jako podejrzane, w wypadku ludzi, którzy postąpili na drodze rozwoju duchowego: brak zdecydowania w dokonanych wyborach, umiłowanie nadzwyczajności, intensywne zmysłowe pociechy, łzy i objawienia ${ }^{30}$.

\footnotetext{
${ }^{27}$ F. Vandenbroucke, Discernement des esprits, k. $1254 \mathrm{n}$.

${ }^{28}$ M.J. Buckley, Discerment of Spirits, s. 279.

${ }^{29}$ J.K. Miczyński, Rozeznawanie duchowe, k. 427.

${ }^{30}$ J. Pegon, Discernement des esprits, k. 1278n.
} 
Z problematyką rozeznawania duchów wiążą się także wspomniane wyżej zjawiska charyzmatyczne w postaci wizji i głosów. Ich doświadczenie zewnętrzne lub wewnętrzne może mieć podłoże zmysłowe (cielesne) i wtedy jest najbardziej narażone na działanie szatana. Może mieć również podłoże wyobrażeniowe i być wynikiem fantazji czy halucynacji, lub być wynikiem działania złego ducha. Może mieć też źródło umysłowe, gdy wiąże się z bierną postawą człowieka oraz brakiem interwencji wyobraźni lub ciała. Na tej podstawie znawcy duchowości formułują różne kryteria oceny zjawisk. Gdy wizje i głosy mają źródło w Bogu, charakteryzują się potęgą, siłą, spokojem, pobożnym skupieniem, długim pozostawaniem w pamięci, jasnością, otwartością i ochoczym przyjęciem decyzji władz kościelnych. Jeśli płyną z wyobraźni, są mniej wyraźne i jasne, nie dają pełni wewnętrznego pokoju i pociechy, mogą być dzielone, skracane i układane przez rozum, czyli poddają się przetworzeniu. Jeśli są wynikiem działania złego ducha, składają się z obrazów już istniejących, poddają się dowolnemu przetwarzaniu, powodują strach i zniewolenie, wchodzą do duszy przez wyobraźnię i zmysły, osłabiają siły do służby Bożej, czynią duszę bardziej egoistyczną i zadufaną w sobie, a także nie prowadzą do głębszej pokory ${ }^{31}$.

Holenderski teolog Kees Waaijman ukazał diakrisis wobrazie, jaki od II wieku zawierają apokryfy, cytując nieznane z Pisma Świętego wezwanie Chrystusa: „Bądźcie mądrymi wekslarzami”. Mądry wekslarz zdaniem Jana Kasjana bada cztery aspekty: 1. Najpierw bada autentyczność monety (czy jest ze złota). 2. Następnie sprawdza, czy wizerunek na niej to król, czy tyran. 3. Analizuje, czy moneta została wybita w autoryzowanym warsztacie, czy u fałszerza. 4 . Wreszcie sprawdza, czy moneta ma pełną wagę. Sprawdzenie, czy moneta jest ze złota, czy z miedzi, to klasyczny biblijny motyw dwóch dróg (por. Ps 1; Pwt 11,26-28): Boga i diabła. Pismo Święte jest „ze złota”, ale można je źle interpretować, nadając mu wyraz tyrana, zamiast widzieć je jako dające wolność słowo Króla. Autoryzowany warsztat oznacza środowisko, wspólnotę, w której rozwija się praktyka duchowa w klimacie roz-

${ }^{31}$ J.K. Miczyński, Rozeznawanie duchowe, k. 427. 
sądnego profesjonalizmu i z uwzględnieniem doświadczeń wielu ludzi. Sprawdzenie wagi oznacza ujęcie różnicy między faktyczną sytuacją, w której ktoś się znajduje, a jego pełną dojrzałością w Bożych oczach ${ }^{32}$.

\section{Pytania otwarte i niejasności w kwestii rozeznania}

W literaturze teologiczno-duchowej pierwsza trudność związana $z$ rozeznawaniem duchów polega na różnym ujęciu działających na człowieka czynników, od prostego opisu dwóch duchów, dobrego i złego, po bardziej skomplikowane teorie. Dominik Schram w Institutiones theologiae mysticae redukuje duchy do jednego dobrego i jednego złego, podczas gdy Miguel Godínez (zm. 1644) w Practica de la teologia mistica wymienia obok ducha Bożego, diabolicznego i ludzkiego, także ducha światowego ${ }^{33}$. Święty Bernard z Clairvaux w De discretione spirituum odróżnia działanie Ducha Świętego, duchów anielskich i diabolicznych, oraz ich satelitów w postaci ducha ciała i świata. Te trzy duchy działają przeciw duszy, ale ona sama też może być źródłem złych pragnień, więc Bernard ma świadomość trudności w odróżnieniu tego, co mówi własny duch, od tego, co mówią trzy złe duchy. Duch ludzki może się też sprzymierzyć z Duchem Bożym, gdy podejmuje dobre natchnienia. Nie jest łatwo rozeznać, czy są one sugestią ducha anielskiego czy Ducha Świętego ${ }^{34}$.

Nawet jeśli poszczególni autorzy osiągają jasność co do ilości badanych czynników, podstawowa trudność polega na ich kompetentnym rozróżnieniu. Klasyk w tej dziedzinie, Jan Ruusbroec, w dziele Cztery pokusy zwraca uwagę na cztery postacie i źródła błędów w rozeznawaniu duchów. Wymienia zmysłowość, obłudę, racjonalizm i fałszywą wolność ${ }^{35}$. To przekonanie prowadzi do wymieniania katalogów trudności związanych z rozeznawaniem, bowiem rozeznający może pod-

\footnotetext{
${ }^{32}$ K. Waaijman, Handbuch der Spiritualität, t. 2, Mainz 2005, s. 188-219.

${ }^{33}$ J. Pegon, Discernement des esprits, k. 1278n.

${ }^{34}$ F. Vandenbroucke, Discernement des esprits, Paris 1957, k. 1255-1257.

${ }^{35}$ Jan van Ruusbroec, Cztery pokusy, [w:] Dzieła, t. 3, Kraków 2003, s. 43-54.
} 
legać iluzji między innymi z powodu: zarozumiałości, pewności siebie i słabej wiary, braku doświadczenia, niedbałości o sprawy duchowe, braku prawej intencji i otwartości na Ducha Świętego, braku głębszego zastanowienia, poczucia samowystarczalności w przeprowadzaniu sądu czy wpływu podświadomości ${ }^{36}$. Warto wspomnieć, że jeden z największych autorytetów życia duchowego, święty Jan od Krzyża, przestrzegał przed poleganiem na słowach sukcesywnych i formalnych słyszanych w duszy, bez względu na to, od jakiego ducha pochodzą. Pisał: „Do tych słów formalnych dusza nie powinna się przywiązywać tak samo, jak i do poprzednich. Wtedy zaprzątałaby ducha tym, co nie jest właściwym i najbliższym środkiem zjednoczenia z Bogiem. Nie szłaby więc drogą wiary i łatwo mogłaby się dać oszukać szatanowi, gdyż nie zawsze można rozeznać, jakie słowa wypowiada duch dobry, a jakie duch zły" ${ }^{37}$.

Już Diadoch z Fotyki w De perfectione spirituali (nr 26) podkreślał trudności w rozeznawaniu, pisząc o demonach przemieniających się w anioły światłości, by łudzić dusze, oraz o osobach, które boleśnie przeżywają czas strapienia, będący w rzeczywistości dobrodziejstwem, jeśli jest przyjęty jako Boża próba. Generalnie teoretycy starożytni interesowali się poruszeniami powodowanymi w duszach przez złe i dobre duchy i podkreślali wagę ich rozróżniania. Niektórzy, jak Orygenes i Kasjan, piszą, że oprócz tego są poruszenia płynące z natury człowieka. Dziś wiele z tych fenomenów, dawniej klasyfikowanych jako anielskie czy diabelskie, w wyniku rozwoju psychiatrii i psychologii uznawane są za naturalne, bez konieczności przypuszczania interwencji preternaturalnej. Obecnie, inaczej niż w starożytności chrześcijańskiej, ważniejsze jest odróżnienie dobrych i złych tendencji, niż naturalnych i preternaturalnych przyczyn ${ }^{38}$. Znane są plastyczne opisy walki ze złymi duchami zawarte w Vita Antonii Atanazego ${ }^{39}$. Od tamtych, bardzo

${ }^{36}$ M. Chmielewski, S. Urbański, Rozeznawanie duchowe, s. 758.

${ }^{37}$ Jan od Krzyża, Droga na górę Karmel, Kraków 2013, s. 277.

${ }^{38}$ G. Bardy, Discernement des esprits, k. 1252-1254.

${ }^{39}$ K. Rahner, „Werdet kundige Geldwechsler“. Zur Geschichte der Lehre des heiligen Ignatius von der Unterscheidung der Geister, [w:] Ignatius von Loyola. Seine geistliche Gestalt und sein Vermächtnis, 1556-1956, F. Wulf (red.), Würzburg 1956, s. 331. 
jednoznacznych opinii, dzieli nas wiele wieków refleksji psychologiczno-teologicznej. Dziś trudność w zdiagnozowaniu działania złego ducha płynie z wielu czynników. Nie można zobaczyć złego ducha, a jedynie doświadczyć jego działania. Ponieważ nie można udowodnić jego obecności, rodzi się problem kompetentnego stwierdzenia, czy osoba prosząca o pomoc jest rzeczywiście dręczona przez złego ducha, czy też cierpi na problemy natury psychicznej. Często może się okazać, że zaistniało jedno i drugie ${ }^{40}$. Dlatego szczególnie problematyczne wydaje się rozeznanie w kontekście odróżnienia opętania i problemów psychicznych. Zarówno teologowie, jak i niektórzy psychiatrzy czy psychoterapeuci widzą konieczność współpracy i uznania granic własnej dziedziny ${ }^{41}$.

Brak jednoznaczności i pewności opisywanych przeżyć prowadzi czasami nawet do pewnego sceptycyzmu teologów wobec doświadczenia chrześcijańskiego jako takiego. Nie jest to bowiem doświadczenie powtarzalne na zasadzie eksperymentu prowokowanej reakcji afektywnej ${ }^{42}$. Można w tym kontekście wskazać na ścisły związek między Duchem Świętym a sumieniem. Dzięki głosowi sumienia Duch Święty przemawia do każdego człowieka, informując go o słuszności lub niesłuszności oceny czynu. W wierzącym to wewnętrzne przewodnictwo sumienia dodatkowo zostaje spotęgowane i uwznioślone przez „namaszczenie”, które poucza o wszystkim, jest prawdziwe i nie jest kłamstwem (por. $1 \mathrm{~J} 2,27)^{43}$. Bóg nie ukrywa przed człowiekiem swojego planu zbawienia, lecz wskutek skażenia natury człowiek nie dość poprawnie rozpoznaje to, co Boże, często myląc je z tym, co ludzkie albo nawet diabelskie. Tymczasem szatan, „ojciec kłamstwa” (J 8,44), na wszelkie sposoby maskuje swoje podstępne działania i podszywa się pod działanie Boże. Obecne czasy naznaczone są postmodernizmem,

${ }^{40}$ F. Mac Nutt, Uwalnianie od złych duchów, Kraków 2012, s. 103.

${ }^{41}$ R. Salvucci, Indicazioni pastorali di un esorcista, Milano 1992, s. 90n.

${ }^{42}$ J. Pegon, Discernement des esprits, k. 1289-1291.

${ }^{43}$ Z.J. Kijas, Traktat o Duchu Świętym i łasce, [w:] Dogmatyka, t. 4, Warszawa 2007, s. 607. 
który upowszechnia relatywizm poznawczo-etyczny. Im bardziej zacierane są kryteria prawdy i kłamstwa, dobra i zła, piękna i kiczu, tym bardziej konieczne jest rozeznanie duchowe. Także szerzący się indyferentyzm i synkretyzm religijny, zwłaszcza w związku z niewłaściwą fascynacją religiami Dalekiego Wschodu, domaga się jasnej oceny postaw religijnych ${ }^{44}$.

\section{Obiektywny i subiektywny aspekt procesu rozeznania}

Wszystkie dotychczasowe rozważania dotykały w dużym stopniu kwestii obiektywnego i subiektywnego aspektu rozeznawania duchów. Zasadniczo już próba określenia, czym jest rozeznanie, pokazuje stały wysiłek, by subiektywne doświadczenie duchowe móc ocenić w świetle pewnych obiektywnych kryteriów. Wynika to z celu rozeznania, skoro ma ono pomóc $\mathrm{w}$ kierownictwie duchowym i szeroko rozumianym duszpasterstwie. Temu też służą kryteria weryfikacji doświadczeń i zjawisk. Wreszcie, jak widzieliśmy, podstawowe problemy i otwarte kwestie rozeznania wiążą się zasadniczo z ustaleniem kryteriów obiektywizujących doświadczenie duchowe. $Z$ drugiej strony kryteria obiektywizujące ocenę płyną również z głębokiego doświadczenia Boga, które w nauczaniu mistrzów duchowości w pewnym momencie stało się klasyczne. Jak już wcześniej wspomniano, samo doświadczenie proroków spotykających Boga było dla nich definitywnym kryterium, choć zawsze w odczytywaniu jego znaczenia odwoływali się oni do tradycji religijnej. W tym sensie kryterium rozeznania prorockiego było zarazem subiektywne i obiektywne ${ }^{45}$.

W chrześcijaństwie od początku rozeznawanie duchów nie było w tym sensie obiektywne, w jakim mógłby być przyjęty raz na zawsze zestaw obiektywnych reguł. Chodziło raczej o to, by wszystko, co stanowi duchowe i społeczne środowisko wspólnoty, jak i duchowe do-

${ }^{44}$ M. Chmielewski, S. Urbański, Rozeznawanie duchowe, s. 757.

${ }^{45}$ J. Guillet, Discernement des esprits, k. 1225-1228. 
świadczenia jej członków, badać i odpowiednio wybierać. Tak więc była to raczej metoda, sposób postępowania, niż treściowe ustalenie. W rozwoju chrześcijaństwa w antycznym i rzymskim świecie ta otwartość proceduralna okazała się owocna dla nauki wiary, praktyki obyczajów, liturgii i sztuki. Obok znaczenia proceduralnego, które na Soborze Watykańskim II zostało podkreślone w formie badania znaków czasu, należy dostrzec znaczenie duchowe i moralne. Chodzi tu bowiem o nabycie osobistej kompetencji, by odróżnić to, co prawdziwe od nieprawdziwego, słuszne od niesłusznego, odpowiednie od nieodpowiedniego. Ta kompetencja może być wzmocniona przez dary Ducha Świętego. Prawdziwy Duch uczy, jak rozróżniać duchy. Z drugiej strony jest ta kompetencja określana mianem cnoty. Musi więc działać w oparciu o sumienie, które jako subiektywna norma winno być ukształtowane w oparciu o normy obiektywne. Szczególnie wielokrotnie przytaczane Ćwiczenia Ignacego podkreślają momenty, w których badane są zarazem obiektywne elementy rozeznawania, jak i głębia subiektywnego, egzystencjalnego doświadczenia ${ }^{46}$.

W chrześcijańskiej tradycji rozeznawania duchów znaczenie ma zarówno wymiar łask gratis datae i habitualnego charyzmatu rozeznawania serca, jak też stopniowa, metodyczna formacja w klasyfikowaniu symptomów, czyli rozeznawanie nabyte. Ważny jest duchowy dar rady i cnota roztropności ${ }^{47}$. Do pewnego stopnia jest to też różnica między spontanicznymi, czyli trudnymi do obiektywnej kontroli Bożymi łaskami, a sprawnościami wypracowanymi w oparciu o poznane rozumem i chciane wolą obiektywne kryteria. Kluczowym zwornikiem tego, co obiektywne i subiektywne w rozeznaniu duchów wydaje się tu ludzkie sumienie, bowiem w normalnym rozwoju życia chrześcijańskiego przychodzi stadium, gdy dusza nie zadowala się już regulowaniem postępowania na podstawie zewnętrznego prawa, bez zasymilowania

${ }^{46}$ D. Mieth, Unterscheidung der Geister, [w:] Lexikon für Theologie und Kirche, t. 10, Freiburg im Breisgau 2006, k. 444n.

${ }^{47}$ J. Pegon, Discernement des esprits. IV. Période moderne, [w:] Dictionnaire de Spiritualité, t. 3, Paris 1957, k. 1275-1278. 
i pokochania go wewnętrznie. W dojrzałej relacji rozeznania kierownik duchowy nie decyduje za kierowanego i jego rada nie jest rozkazem, ale pomocą $\mathrm{w}$ rozwoju sumienia ${ }^{48}$.

\section{Summary}

Within Christianity there is a profound expectation to be guided by the Spirit. Such an expectation, both of a person and of the Church itself, tend to put emphasis upon religious experience that engages the entire way of life of the community. The intensity of this experience does not absolve one from discretion, critical reflection and doctrinal content of Christian faith. Discernment of spirits can be understood as an infused gift of the Spirit, as a connatural sensibility or as knowledge learned from study. In the history of Christian spirituality the spiritual authors have tried to prove that the discerning of spirits is objective, not subjective. Discernment should be a part of everyone's spiritual journey. No one should attempt to make spiritual progress alone. A spiritual director is required to assist a Christian in examining life according to his or her own conscience.

Keywords: Discernment of Spirits, Spiritual Life, Spiritual Theology, Spiritual Masters

${ }^{48}$ J. Pegon, Discernement des esprits. VI. Conclusion, [w:] Dictionnaire de Spiritualité, t. 3, Paris 1957, k. 1286-1288. 


\section{Bibliografia}

Augustyn J., Świat ludzkich uczuć, [w:] Droga ćwiczeń, Czechowice-Dziedzice 1991, s. 19-32.

Bardy G., Discernement des esprits. II. Chez les Pères, [w:] Dictionnaire de Spiritualité, t. 3, Paris 1957, k. 1247-1254.

Barruffo A., Discernimento, [w:] Nuovo dizionario di spiritualità, Torino 1985, s. 419-430.

Buckley M.J., Discerment of Spirits, [w:] The New Dictionary of Catholic Spirituality, M. Downey (red.), Collegeville 1993, s. 274-281.

Chmielewski M., Urbański S., Rozeznawanie duchowe, [w:] Leksykon duchowości katolickiej, Lublin-Kraków 2002, s. 757n.

Duch, [w:] Słownik Teologii Biblijnej, X. Leon-Dufour (red.), Poznań-Warszawa 1973, s. 225.

Franciszek, Adhortacja apostolska Evangelii gaudium, Watykan 2013.

Guillet J., Discernement des esprits. I. Dans l'Écriture, [w:] Dictionnaire de Spiritualité, t. 3, Paris 1957, k. 1222-1247.

Hilberath B.J., Pneumatologie, [w:] Handbuch der Dogmatik, t. 1, T. Schneider (red.), Düsseldorf 2006, s. 445-552.

Jan od Krzyża, Droga na górę Karmel, Kraków 2013.

Jan van Ruusbroec, Cztery pokusy, [w:] Dzieła, t. 3, Kraków 2003, s. 43-54.

Kijas Z.J., Traktat o Duchu Świętym i łasce, [w:] Dogmatyka, t. 4, Warszawa 2007.

Mac Nutt F., Uwalnianie od złych duchów, Kraków 2012.

Martin H., Discernement des esprits. V. Discernement des esprits et direction spirituelle, [w:] Dictionnaire de Spiritualité, t. 3, Paris 1957, k. 1281-1285.

Miczyński J.K., Rozeznawanie duchowe, [w:] Encyklopedia Katolicka t. 17, E. Gigilewicz (red.), Lublin 2012, k. 426n.

Mieth D., Unterscheidung der Geister, [w:] Lexikon für Theologie und Kirche, t. 10, Freiburg im Breisgau 2006, k. 444n.

Nocoń A., Władza złych duchów nad człowiekiem według Jana Kasjana, „Vox Patrum" 33(2013)59, s. 197-208.

Pegon J., Discernement des esprits. IV. Période moderne, [w:] Dictionnaire de Spiritualité, t. 3, Paris 1957, k. 1266-1279.

Pegon J., Discernement des esprits. VI. Conclusion, [w:] Dictionnaire de Spiritualité, t. 3, Paris 1957, k. 1286-1291.

Rahner K., „Werdet kundige Geldwechsler“. Zur Geschichte der Lehre des heiligen Ignatius von der Unterscheidung der Geister, [w:] Ignatius von Loyola. 
Seine geistliche Gestalt und sein Vermächtnis, 1556-1956, F. Wulf (red.), Würzburg 1956, s. 301-341.

Salvucci R., Indicazioni pastorali di unesorcista, Milano 1992.

Semplici S., Czas jest ważniejszy niż przestrzeń, „Społeczeństwo” 4(2014), s. $84-94$.

Siebenrock R.A., Die Wahrheit der Religionen und die Fülle der Selbstmitteilung Gottes in Jesus Christus, [w:] Herders Theologischer Kommentar zum Zweiten Vatikanischen Konzil, t. 5, Freiburg im Breisgau 2006.

Spadaro A., Serce wielkie i otwarte na Boga. Wywiad z papieżem Franciszkiem, Dodatek do tygodnika „Gość Niedzielny” 2013, nr 40, s. 12.

Stein E., Sanctadiscretio, [w:] Edith Stein Gesamtausgabe. Geistliche Texte II, Freiburg im Breisgau 2007, s. 114-117.

Prusak J., Strapienie i pocieszenie. Jak kierować się uczuciami w życiu duchowym, [w:] J. Augustyn, J. Kołacz (red.), Sztuka kierownictwa duchowego, Kraków 2013, s. 415-422.

Vandenbroucke F., Discernement des esprits. III. Au Moyen Age, [w:] Dictionnaire de Spiritualité, t. 3, Paris 1957, k. 1254-1266.

Waaijman K., Handbuch der Spiritualität, t. 2, Mainz 2005. 


\section{Część II}

Idea rozeznania

we współczesnych dokumentach Kościoła 
